\title{
Karakteristik Agronomis Tiga Varietas Padi (Oryza sativa L.) pada Dua Sistem Tanam Benih di Lahan Pasang Surut
}

\section{Agronomic Characteristic of Three Rice Varieties (Oryza sativa L.) on Two Seed Planting Systems in Tidal Land}

\author{
Haris Kriswantoro ${ }^{1,2, *}$, Etty Safriyani ${ }^{2,3}$, Purwaningsih ${ }^{4}$, dan Siti Herlinda ${ }^{2}$ \\ ${ }^{1}$ Program Studi Agroteknologi, Fakultas Pertanian, Universitas Palembang \\ ${ }^{2}$ Program Doktor, Fakultas Pertanian, Universitas Sriwijaya \\ ${ }^{3}$ Program Studi Agroteknologi, Fakultas Pertanian, Universitas Musi Rawas \\ ${ }^{4}$ Alumni Program Studi Agroteknologi, Fakultas Pertanian, Universitas Musi Rawas
}

Diterima 30 Maret 2017/Disetujui 22 Maret 2018

\begin{abstract}
The efforts to develop and increase rice production in tidal land need appropriate technologies including adaptable superior varieties and efficient seed planting system. This study was aimed to measure the agronomic characteristic of the three rice varieties on the systems of in-row direct seeding and broadcast in tidal land. The experiment was carried out at type B of tidal land in Sidoharjo Village, Air Saleh Subdistrict, Banyuasin District, from January to April 2016. The experiment was conducted using split plot design with four replications. The main plot was seed planting system, consisted of in-row direct seeding system and broadcast system; whereas subplot was three rice varieties, consisted of Inpari 22, Inpara 4, and Ciherang. Result of LSD test on interaction showed that though the best growth was obtained from the combination of Inpari 22 and in-row direct seeding and very significant with the others, but its yield was not significant with the combination of Inpara 4 and in-row direct seeding. It was concluded that Inpari 22 and Inpara 4 with in-row direct seeding system showed better growth and higher yield than Inpari 22, Inpara 4 and Ciherang with broadcast system in tidal lands. Ciherang was not suitable in tidal land, while Inpari 22 was suitable.
\end{abstract}

Keywords: broadcast system, in-row direct seeding system, production

\section{ABSTRAK}

Upaya pengembangan dan peningkatan produksi padi di lahan pasang surut membutuhkan teknologi yang tepat diantaranya varietas unggul yang adaptif dan sistem tanam benih yang efisien. Penelitian ini bertujuan membandingkan karakteristik agronomis tiga varietas padi pada sistem tanam benih dalam alur dan sistem sebar di lahan pasang surut. Penelitian telah dilaksanakan di lahan pasang surut tipe luapan B di Desa Sidoharjo, Kecamatan Air Saleh, Kabupaten Banyuasin, pada bulan Januari hingga April 2016. Penelitian menggunakan rancangan split plot dengan empat ulangan. Petak utama adalah sistem tanam benih, terdiri dari sistem alur dan sistem sebar, sedangkan anak petak adalah varietas padi, terdiri dari Inpari 22, Inpara 4, dan Ciherang. Uji BNT terhadap interaksi perlakuan memperlihatkan, walaupun pertumbuhan terbaik diperoleh pada kombinasi Inpari 22 dengan sistem alur dan berbeda sangat nyata dengan kombinasi lainnya, namun produksinya berbeda tidak nyata dengan kombinasi Inpara 4 pada sistem alur. Disimpulkan bahwa Inpari 22 dan Inpara 4 pada sistem alur menunjukkan pertumbuhan yang lebih baik dan produksi yang lebih tinggi dibandingkan Inpari 22, Inpara 4, dan Ciherang pada sistem sebar di lahan pasang surut. Ciherang tidak cocok untuk lahan pasang surut, sedangkan Inpari 22 cocok di lahan pasang surut.

Kata kunci: produksi, sistem alur, sistem sebar

\section{PENDAHULUAN}

Pengembangan tanaman padi dalam rangka mewujudkan ketahanan pangan nasional, saat ini diarahkan

\footnotetext{
* Penulis untuk korespondensi. e-mail: harisk@student.pps.unsri. ac.id
}

dengan memanfaatkan lahan-lahan suboptimal yang masih tersedia dan memungkinkan untuk dikelola sebagai lahan produksi pangan (Lakitan dan Ghofar, 2013). Salah satu areal alternatif yang memiliki prospek besar dari segi potensi luas maupun daya dukung agronomis untuk dijadikan sebagai areal produksi padi adalah lahan pasang surut (Arsyad et al., 2014). 
Pemanfaatan lahan pasang surut di Sumatera Selatan belum optimal karena adanya berbagai kendala, di antaranya adalah kesuburan tanah yang rendah, reaksi tanah yang masam, adanya pirit, tingginya kadar $\mathrm{Al}, \mathrm{Fe}, \mathrm{Mn}$, dan asam organik, kahat $\mathrm{P}$, miskin kation basa seperti $\mathrm{Ca}$, $\mathrm{K}, \mathrm{Mg}$, serta tertekannya aktivitas mikroba (Arsyad et al., 2014). Indikasinya terlihat dari tingkat produksi yang masih rendah dan belum meningkatnya kesejahteraan petani pada umumnya (Raharjo et al., 2013). Produksi padi di lahan pasang surut berkisar antara 2.6-4 ton GKG ha ${ }^{-1}$, sedangkan beberapa hasil penelitian menunjukkan bahwa potensi produksi padi di lahan tersebut berkisar 6.3-7.0 ton GKG ha $^{-1}$ (Alwi, 2014).

Permasalahan dalam pengelolaan lahan pasang surut perlu diatasi, untuk itu diperlukan beberapa komponen teknologi optimalisasi lahan pasang surut dalam budidaya tanaman padi di antaranya pemilihan varietas unggul padi adaptif (Arsyad et al., 2014), dan penggunaan alat mesin tanam benih (Umar, 2013). Sistem tanam benih dapat dilakukan dengan cara tabur benih langsung (tabela) yang dapat menjadi alternatif bagi petani terutama di daerah dengan tenaga kerja terbatas dan mahal, sementara harga mesin tanam pindah tidak terjangkau petani. Selain itu, sistem tanam benih dapat juga dilakukan dengan cara penaburan benih dalam larikan menggunakan alat yang disebut "atabela" (alat tanam benih langsung) (Pane, 2003). Penggunaan sistem tanam benih tabela dan atabela dapat mempercepat masa panen, menghemat pemakaian benih, menghemat kebutuhan air hingga $20 \%$ per musimnya, menghemat kebutuhan tenaga kerja tanam, hasil produksi lebih tinggi dan tanaman lebih tahan terhadap serangan hama penggerek batang (Salimin, 2012).

Penggunaan varietas unggul yang cocok dan adaptif merupakan salah satu komponen teknologi yang nyata kontribusinya terhadap peningkatan produktivitas padi, cepat diadopsi petani karena murah dan penggunaannya lebih praktis (Saidah et al., 2015). Varietas unggul yang mampu beradapatasi dengan lingkungan yang spesifik dapat memberikan hasil yang lebih optimal daripada varietas dengan adaptasi luas (Zein, 2012). Varietas padi unggul nasional juga dapat beradaptasi dengan baik di lahan pasang surut dengan hasil yang cukup tinggi (Arsyad et al., 2014). Penelitian ini bertujuan untuk membandingkan karakteristik agronomis tiga varietas padi (Oryza sativa L.) pada sistem tanam benih dalam alur dan sistem sebar di lahan pasang surut.

\section{BAHAN DAN METODE}

Penelitian telah dilaksanakan di lahan pasang surut tipe luapan B di Desa Sidoharjo, Kecamatan Air Saleh, Kabupaten Banyuasin dengan ketinggian tempat $3.5 \mathrm{~m}$ dpl dengan topografi tanah datar, bergelombang dengan kemiringan $<6 \%$ dan sangat dipengaruhi luapan air pasang secara langsung atau tidak langsung dengan derajat keasaman 3.5-5.0, suhu udara $26-34{ }^{\circ} \mathrm{C}$ dan $\mathrm{RH} 75-90 \%$. Waktu penelitian dimulai pada bulan Januari hingga April 2016. Penelitian menggunakan metode eksperimental split plot dengan empat ulangan, yaitu (1) sebagai petak utama adalah sistem tanam benih yang terdiri dari 2 macam, yaitu sistem tanam benih dalam alur dengan menggunakan alat tabur benih langsung (atabela), dan sistem sebar dengan cara penaburan benih langsung (tabela); (2) sebagai anak petak adalah varietas padi terdiri dari 3 macam, yaitu Inpari 22, Inpara 4, dan Ciherang.

Penanaman dilakukan pada areal tanam seluas $720 \mathrm{~m}^{2}$. Sebelum ditanam, tanah diolah terlebih dahulu menggunakan traktor, lalu ditaburi dolomit sebanyak 40 $\mathrm{kg} \mathrm{ha}^{-1}$ dan dipupuk dengan pupuk kotoran ayam sebanyak 2 ton $\mathrm{ha}^{-1}$. Selanjutnya dibuat petakan percobaan dengan ukuran masing-masing $7.5 \mathrm{~m} \mathrm{x} 4 \mathrm{~m}$.

Benih padi dari masing-masing varietas ditanam sesuai dengan perlakuan, yaitu dengan sistem alur dan sistem sebar. Kebutuhan benih untuk sistem alur sebanyak $10 \mathrm{~kg} \mathrm{ha}^{-1}$, sedangkan sistem sebar sebanyak $15 \mathrm{~kg} \mathrm{ha}^{-1}$. Benih yang diperlukan pada sistem sebar lebih banyak daripada sistem alur, karena selain untuk mendapatkan hasil yang tinggi juga untuk menekan infestasi gulma (Pane, 2003). Kegiatan penaburan benih sistem alur dengan atabela (alat tabur benih langsung), dilakukan dengan cara benih padi dimasukkan kedalam pipa paralon berdiameter $1.3 \mathrm{~cm}$ dengan ukuran jarak tanam $20 \mathrm{~cm}$ x $25 \mathrm{~cm}$, dan selanjutnya atabela ditarik langsung oleh manusia dan dengan sendirinya benih padi akan keluar sesuai jarak tanam yang telah diatur melalui atabela tersebut. Kegiatan penaburan benih dengan sistem sebar, dilakukan dengan cara benih ditabur langsung (tabela) ke petak penanaman, kemudian benih tersebut ditutup kembali.

Pemberian pupuk SP-36 sebanyak $75 \mathrm{~kg} \mathrm{ha}^{-1}$ dan $\mathrm{KCl}$ sebanyak $50 \mathrm{~kg} \mathrm{ha}{ }^{-1}$ dilakukan 1 minggu setelah penanaman dengan cara disebar di atas permukaan tanah. Pupuk urea diberikan saat tanaman berumur 21 hari setelah tanam dengan dosis $200 \mathrm{~kg} \mathrm{ha}^{-1}$ yang diberikan dengan cara disebar.

Kegiatan pemeliharaan meliputi: (1) pengaturan air yang disesuaikan dengan kondisi tanaman dan tanah, dengan cara mengatur keluar masuknya air dari petak penanaman melalui parit atau saluran drainase. Pengaturan keluar masuknya air dalam penelitian ini adalah saat pengolahan tanah, air dari parit-parit yang ada hanya diambil resapannya saja karena pada bulan Januari kondisi air dalam keadaan masam. Setelah padi berumur 1 bulan hingga padi memasuki fase pengisian bulir dan bersamaan dengan naiknya curah hujan, pintu air irigasi dibuka karena akan terjadi keadaan pasang besar sehingga mampu mencukupi kebutuhan air bagi tanaman padi. Saat menjelang panen yaitu 10 hari sebelum panen dilakukan pengeringan dengan menutup pintu air irigasi sehingga volume air yang masuk sedikit dan kegiatan pengeringan lahan dilakukan untuk mempercepat penurunan kadar air gabah dan memudahkan dalam pelaksanaan pemanenan; (2) pengendalian hama dan penyakit dilakukan dengan menggunakan pestisida, sedangkan pengendalian gulma menggunakan herbisida dan secara manual disesuaikan dengan kondisi di lapangan.

Kegiatan pengamatan pada masing-masing petakan dibuatkan subpetak yang berukuran $2.5 \mathrm{~m}$ x $2.5 \mathrm{~m}$ sebagai 
ulangan. Setiap subpetak diambil sampel tanaman sebanyak 5 persen dari total tanaman dalam subpetak. Sampel tanaman digunakan untuk mengukur peubah-peubah komponen pertumbuhan dan komponen hasil.

Peubah yang diamati adalah: (a) tinggi tanaman (cm), diukur dari pangkal batang hingga ujung daun tertinggi, dilakukan saat tanaman mendekati panen, (b) jumlah anakan produktif, dihitung semua anakan yang mengeluarkan malai pada setiap rumpun, (c) umur berbunga hari setelah tanam (hst) diukur saat $50 \%$ dari populasi tanaman mulai mengeluarkan malai, (d) jumlah gabah bernas (biji), dihitung semua gabah yang berisi pada setiap malai, (e) bobot 1,000 biji, diukur dengan cara mengambil 1,000 butir gabah pada kadar air 18\%, (f) produksi gabah (ton ha-1), diukur segera setelah panen (kadar air 20\%) (g), bobot gabah kering panen/GKP (ton ha-1) diukur setelah gabah dirontokkan dan dijemur di lantai penjemur hingga mencapai kadar air $18 \%$, dan (h) bobot gabah kering giling/GKG (ton ha ${ }^{-1}$ ) dihitung dengan cara mengkonversi bobot GKP ke bobot GKG (kadar air 14\%), dengan rumus = bobot GKP x 86\%. Selanjutnya, data hasil pengamatan diolah secara statistik menggunakan analisis ragam. Jika perlakuan berpengaruh nyata dilanjutkan dengan uji Beda Nyata Terkecil (BNT) pada taraf 5\% (Steel dan Torrie, 1995).

\section{HASIL DAN PEMBAHASAN}

Pertumbuhan Inpari 22 pada sistem alur berdasarkan rata-rata tinggi tanaman dan jumlah anakan produktif lebih baik dan berbeda nyata dengan kombinasi lainnya, sedangkan terhadap peubah produksi gabah, bobot GKP dan bobot GKG berbeda tidak nyata dengan Inpara 4 pada sistem alur (Tabel 1). Pertumbuhan dan hasil tanaman padi yang berbeda akibat perbedaan varietas/kultivar dan sistem tanam benih, juga dilaporkan oleh Akhgari dan Kaviani (2011) dan Rana et al. (2014). Meningkatnya pertumbuhan yang diikuti dengan meningkatnya komponen hasil (jumlah gabah bernas dan bobot 1,000 butir) (Tabel 2) pada varietas Inpari 22 dan Inpara 4 memberikan pengaruh yang besar terhadap hasil kedua varietas tersebut, meskipun umur berbunga berbeda tidak nyata.

Perbedaan kondisi lingkungan terjadi akibat penggunaan sistem alur dan sistem sebar, sehingga menghasilkan jarak tanam dan populasi tanaman yang berbeda, telah mempengaruhi kondisi lingkungan mikro di sekitar tanaman yang dapat dimanfaatkan oleh tanaman padi sesuai dengan potensi genetis masing-masing varietas. Hal tersebut selanjutnya berpengaruh terhadap pertumbuhan dan produksi tanaman. Kondisi lingkungan yang demikian, ternyata dapat dimanfaatkan dengan baik oleh Inpari 22 dan Inpara 4, karena kedua varietas tersebut merupakan varietas yang dianjurkan untuk lahan pasang surut, dan sudah beradaptasi pada kondisi lingkungan di lahan pasang surut. Kerapatan tanam yang lebih teratur akibat penggunaan sistem alur mampu dimanfaatkan kedua varietas tersebut untuk menggunakan sumberdaya secara optimal, baik ruang tumbuh, unsur hara, air, dan cahaya matahari; sehingga tanaman padi mampu memberikan hasil terbaik dibandingkan dengan kombinasi perlakuan lainnya. Marpaung et al. (2013) menjelaskan bahwa, tanaman yang memiliki kerapatan rendah dan teratur, dapat menjadikan tanaman mampu memanfaatkan faktor-faktor tumbuh yang

Tabel 1. Pengaruh interaksi sistem tanam benih dan varietas terhadap pertumbuhan dan produksi padi

\begin{tabular}{|c|c|c|c|}
\hline \multirow{2}{*}{$\begin{array}{l}\text { Sistem } \\
\text { Tanam }\end{array}$} & \multicolumn{3}{|c|}{ Varietas } \\
\hline & Inpari 22 & Inpara 4 & Ciherang \\
\hline & \multicolumn{3}{|c|}{ 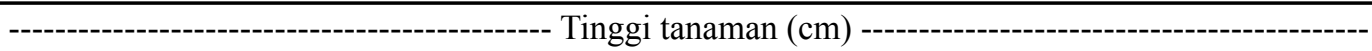 } \\
\hline Alur & $99.35 \mathrm{a}$ & $89.78 b c$ & $70.32 \mathrm{e}$ \\
\hline Sebar & $85.70 \mathrm{c}$ & $91.45 b$ & $75.65 \mathrm{~d}$ \\
\hline & & anakan pr & ------- \\
\hline Alur & $18.35 \mathrm{a}$ & $16.00 \mathrm{~b}$ & $7.90 \mathrm{~d}$ \\
\hline \multirow[t]{2}{*}{ Sebar } & $16.45 b$ & $13.70 \mathrm{c}$ & $6.90 \mathrm{e}$ \\
\hline & & ksi gabah & \\
\hline Alur & $7.13 \mathrm{a}$ & $6.76 \mathrm{a}$ & $3.38 b$ \\
\hline \multirow[t]{2}{*}{ Sebar } & $2.67 \mathrm{c}$ & $2.65 \mathrm{c}$ & $1.08 \mathrm{~d}$ \\
\hline & - & kering pa & 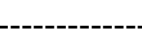 \\
\hline Alur & $6.72 \mathrm{a}$ & $6.40 \mathrm{a}$ & $3.19 \mathrm{~b}$ \\
\hline \multirow[t]{2}{*}{ Sebar } & $2.56 \mathrm{c}$ & $2.53 \mathrm{c}$ & $0.99 \mathrm{~d}$ \\
\hline & & h kering & \\
\hline Alur & $5.73 \mathrm{a}$ & $5.45 \mathrm{a}$ & $2.70 \mathrm{~b}$ \\
\hline Sebar & $2.14 \mathrm{c}$ & $2.00 \mathrm{c}$ & $0.80 \mathrm{~d}$ \\
\hline
\end{tabular}

Keterangan: Angka-angka yang diikuti oleh huruf yang sama pada baris dan kolom yang sama berarti berbeda tidak nyata pada taraf uji BNT 5\% 
tersedia secara optimal seperti cahaya matahari, air, dan $\mathrm{CO}_{2}$ dengan lebih baik untuk pertumbuhan dan pembentukan hasil, karena kompetisi yang terjadi relatif kecil.

Sementara itu, pertumbuhan yang lebih baik dan produksi yang tinggi pada Inpari 22 dan Inpara 4 menunjukkan bahwa Inpari 22 dan Inpara 4 merupakan varietas unggul yang adaptif di lahan pasang surut. Inpara 4 merupakan Inbrida Padi Rawa yang dihasilkan Balitbangtan yang telah teruji sesuai untuk lahan pasang surut; varietas unggul tersebut berumur lebih pendek dan berdaya hasil lebih tinggi (Arsyad et al., 2014). Beberapa varietas Inpari (Inbrida Padi Irigasi) di antaranya Inpari 22 merupakan varietas padi yang mampu memberikan hasil panen tertinggi di daerah rawa (Waluyo dan Suparwoto, 2014). Inpari 22 dan Inpara 4 merupakan varietas tanaman padi yang tumbuh tegak dan tidak mudah rebah. Kondisi demikian memungkinkan tanaman dapat memanfaatkan secara optimal cahaya matahari yang jatuh ke permukaan daun, sehingga meningkatkan laju fotosintesis dan selanjutnya dapat mendorong pertumbuhan dan perkembangan tanaman yang lebih baik. Ketersediaan cahaya matahari yang optimal dapat meningkatkan source dan kekuatan sink pada tanaman padi (Saidah et al., 2015). Sementara Razie et al. (2013) melaporkan bahwa produksi padi Ciherang di lahan pasang surut dengan budidaya SRI hampir 22\% lebih tinggi dibandingkan dengan budidaya konvensional.

Pertumbuhan yang lebih baik dan produksi yang lebih tinggi dari varietas Inpari 22, Inpara 4, dan Ciherang pada sistem alur dibandingkan dengan sistem sebar (Tabel 1 dan Tabel 2), dikarenakan dengan menerapkan sistem tanam benih dalam alur menyebabkan kerapatan tanaman padi lebih teratur. Konsekuensi yang diperoleh dari jarak tanam yang teratur akan mengurangi kompetisi untuk mendapatkan faktor-faktor produksi antar tanaman (Usman et al., 2014). Penampilan tanaman padi yang lebih baik dan secara nyata lebih tinggi pada sistem alur dibandingkan dengan sistem sebar dan sistem tanam pindah, juga dilaporkan oleh Laary et al. (2012). Pengembangan sistem alur mempunyai prospek yang lebih baik daripada sistem sebar, karena hasil panen lebih tinggi dan pemeliharaan tanaman lebih mudah (Pane, 2003). Sebaliknya, rendahnya produksi padi pada sistem sebar dikarenakan kerapatan tanam yang kurang teratur, sehingga meningkatkan serangan hama dan penyakit (Arfah et al., 2013), serta meningkatnya persaingan dengan gulma (Farooq et al., 2011). Sementara itu, Naresh et al. (2013) dan Raharjo et al. (2013) melaporkan, bahwa tidak ada perbedaan yang nyata pertumbuhan dan produksi beberapa varietas/kultivar padi yang diuji akibat sistem tanam benih.

Tabel 2. Rata-rata umur berbunga, jumlah gabah bernas dan bobot 1,000 butir pada perlakuan sistem tanam benih dan varietas

\begin{tabular}{lccc}
\hline \multirow{2}{*}{ Perlakuan } & \multicolumn{3}{c}{ Rata-rata } \\
\cline { 2 - 4 } & Umur berbunga (hst) & Jumlah gabah bernas (biji) & Bobot 1,000 butir (g) \\
\hline Sistem tanam & & $113.55 \mathrm{a}$ & 25.20 \\
Alur & 74.33 & $100.62 \mathrm{~b}$ & 25.83 \\
Sebar & 74.33 & & $25.31 \mathrm{~b}$ \\
Varietas & & $108.20 \mathrm{~b}$ & $29.70 \mathrm{a}$ \\
Inpari 22 & 75.00 & $112.78 \mathrm{a}$ & $21.54 \mathrm{c}$ \\
Inpara 4 & 75.00 & $100.28 \mathrm{c}$ & \\
Ciherang & 73.00 & & \\
\hline
\end{tabular}

Keterangan: Angka-angka yang diikuti oleh huruf yang sama pada kolom yang sama berarti berbeda tidak nyata pada taraf uji BNT 5\%

\section{KESIMPULAN}

Inpari 22 dan Inpara 4 pada sistem alur menunjukkan pertumbuhan yang lebih baik dan produksi yang lebih tinggi dibandingkan Inpari 22, Inpara 4, dan Ciherang pada sistem sebar di lahan pasang surut. Inpari 22, padi lahan irigasi, mampu berproduksi setara dengan Inpara 4 pada lahan pasang surut. Ciherang, padi lahan irigasi, tidak sesuai untuk lahan pasang surut.

\section{DAFTAR PUSTAKA}

Akhgari, H., B. Kaviani. 2011. Assessment of direct seeded and transplanting methods of rice cultivars in the Northern Part of Iran. African J. Agric. Res. 6(31):6492-6498.
Alwi, M. 2014. Prospek lahan rawa pasang surut untuk tanaman padi. Hal. 45-49. Dalam Prosiding Seminar Nasional "Inovasi Teknologi Pertanian Spesifik Lokasi”, Banjarbaru 6-7 Agustus 2014.

Arfah, S.Y.C., R.A. Rauf, Sulaiman. 2013. Analisis komparatif pendapatan usahatani padi sawah sistem tabela dan sistem tapin. e-J. Agrotekbis 1:244-249.

Arsyad, D.M., B.B. Saidi, Enrizal. 2014. Pengembangan inovasi pertanian di lahan rawa pasang surut mendukung kedaulatan pangan. J. Pengembangan Inovasi Pertanian 7:169-176 
Farooq, M., K.H.M. Siddique, H. Rehman, T. Aziz, D.J. Lee, A. Wahid. 2011. Rice direct seeding: experiences, challenges and opportunities. Soil Tillage Res. 111:87-98.

Laary, J.K., W. Dogbe, P. O. Boamah, J. Agawini. 2012. Evaluation of planting methods for growth and yield of "Digang" rice (Oryza sativa L.) under upland condition of Bawku, Upper East Region, Ghana. ARPN J. Agric. Biol. Sci. 7:814-819.

Lakitan, B., N. Ghofar. 2013. Kebijakan inovasi teknologi untuk pengelolaan lahan suboptimal berkelanjutan. Hal. 5-14. Dalam S. Herlinda, B. Lakitan, Sobir, Koesnandar, Suwandi, Puspitahati, M.I. Syafutri, D. Meidalima (Eds.). Prosiding Seminar Nasional Lahan Suboptimal "Intensifikasi Pengelolaan Lahan Suboptimal dalam Rangka Mendukung Kemandirian Pangan Nasional", Palembang 20-21 September 2013.

Marpaung, S., Y. Parto, E. Sodikin. 2013. Evaluasi kerapatan tanam dan metode pengendalian gulma pada budidaya padi tanam benih langsung di lahan sawah pasang surut. J. Lahan Suboptimal 2:93-99.

Naresh, R.K., A.K. Misra, S.P. Singh. 2013. Assessment of direct seeded and transplanting methods of rice cultivars in the western part of Uttar Pradesh. Internat. J. Pharmaceutical Sci. Business Manag. 1:1-8.

Pane, H. 2003. Kendala dan peluang pengembangan teknologi padi tanam benih langsung. J. Litbang Pertanian 22:172-178.

Raharjo, B., I. S. Marpaung, Y Hutapea. 2013. Kajian kinerja alat tanam dan varietas unggul baru padi di lahan pasang surut Sumatera Selatan. Jurnal Pengkajian dan Pengembangan Teknol. Pertanian 16:191-201.

Rana, Md. M., Md. A. A. Mamun, A. Zahan, Md. N. Ahmed, Md. A. J. Mridha. 2014. Effect of planting methods on the yield and yield attributes of short duration Aman rice. Amer. J. Plant Sci. 5:251-255.

Razie, F., I. Anas, A. Sutandi, Sugiyanta, L. Gunarto. 2013. Efisiensi serapan hara dan hasil padi pada budidaya SRI di persawahan pasang surut dengan menggunakan kompos diperkaya. J. Agron. Indonesia 41:89-97.

Saidah, A., Irmadamayanti, Syafrudin. 2015. Pertumbuhan dan produktivitas beberapa varietas unggul baru dan lokal padi rawa melalui pengelolaan tanaman terpadu di Sulawesi Tengah. Pros Sem Nas Masy Biodiv Indon 1:935-940 DOI: $10.13057 / \mathrm{psnmbi} / \mathrm{m} 010450$

Salimin. 2012. Perencanaan alat tabur benih padi langsung. Dinamika J. Ilmiah Teknik Mesin 3:245-250.

Steel, R.G.D., J.H. Torrie. 1995. Prinsip dan Prosedur Statistik. Gramedia. Jakarta, ID.

Umar, S. 2013. Pengelolaan dan pengembangan alsintan untuk mendukung usahatani padi di lahan pasang surut. J. Teknologi Pertanian 8:37-48.

Usman, Z., U. Made, Adrianton. 2014. Pertumbuhan dan hasil tanaman padi (Oryza sativa L.) pada berbagai umur semai dengan teknik budidaya SRI (System of Rice Intensification). e-J. Agrotekbis 2:32-37.

Waluyo, Suparwoto. 2014. Pengkajian beberapa varietas unggul baru (VUB) padi di lahan rawa lebak Kabupaten Ogan Ilir Sumatera Selatan. Hal. 2129. Dalam S. Herlinda, Suwandi, F.H. Taqwa, Tanbiyaskur, E. Handayanto, H.M. Sarjan, N. Aini, Rajiman, Mardhiana (Eds.). Prosiding Seminar Nasional Lahan Suboptimal 2014, Palembang 26-27 September 2014.

Zein, S. 2012. Parameter genetik padi sawah dataran tinggi. J. Penelitian Pertanian Terapan 12:196-201. 